\title{
Legitimacy and Lawmaking: A Tale of Three International Courts
}

\author{
Laurence R. Helfer and Karen J. Alter*
}

This Article explores the relationship between the legitimacy of international courts (ICs) and expansive judicial lawmaking. We compare lawmaking by three regional integration courts - the Court of Justice of the European Union (CJEU), the Andean Tribunal of Justice (ATJ), and the ECOWAS Community Court of Justice (ECCJ). These courts have similar jurisdictional grants and access rules, yet each has behaved in a strikingly different way when faced with opportunities to engage in expansive judicial lawmaking. The CJEU is the most activist, but its audacious legal doctrines have been assimilated as part of the court's legitimate authority. The ATJ and ECOWAS have been more cautious, but there is little to suggest that this caution has enhanced the legitimacy of either court. The ATJ has avoided serious challenges from governments, but its rulings have had little political impact. Conversely, the ECCJ's circumspection has not shielded it from political opposition to its adjudication of clearly-established human rights. This pattern is at odds with the oft-voiced conventional wisdom that expansive judicial lawmaking undermines judicial legitimacy. Our modest goal in this Article is to problematize that claim and to posit an alternative hypothesis that ICs spark legitimacy challenges due to the domestic political effects of their decisions, regardless of whether those decisions are expansionist.

* Laurence R. Helfer is Harry R. Chadwick, Sr. Professor of Law, Duke University. Karen J. Alter is Professor of Political Science and Law, Northwestern University, and Senior Researcher, iCourts: Centre of Excellence for International Courts, University of Copenhagen. 


\section{INTRODUCTION}

The last decade has witnessed a dramatic and rapid judicialization of international law. International courts and tribunals (ICs) now exercise jurisdiction over subjects as diverse as human rights, criminal law, trade, investment, and environmental protection. They include institutions that range from permanent courts to quasi-judicial and ad hoc review mechanisms, to international arbitral bodies. And they have left no region of the world untouched, extending their geographic reach to countries large and small, and rich and poor. ${ }^{1}$

Spurred by the creation of new ICs, their swelling dockets, and the widening political impact of their rulings, scholars have created a cottage industry devoted to the study of international adjudication. The Project on International Courts and Tribunals and individual scholars have supplied new empirical evidence. ${ }^{2}$ Oxford University Press has created a book series with more than a dozen volumes and a forthcoming Handbook of International Adjudication. ${ }^{3}$ Martinus Nijhoff has launched a new specialized journal. ${ }^{4}$ Several universities have established centers devoted to ICs. ${ }^{5}$ And journals are replete with symposia analyzing the law and politics of international adjudication. ${ }^{6}$

1 See, e.g., Karen J. Alter, The New Terrain of International Law (2013); Gary Born, A New Generation of International Adjudication, 61 Duke L.J. 775 (2012); Laurence R. Helfer \& Anne-Marie Slaughter, Why States Create International Tribunals: A Response to Professors Posner and Yoo, 93 Calif. L. Rev. 899 (2005).

2 Project on Int'l Courts \& Tribunals, http://www.pict-pcti.org/ (last visited Nov. 28, 2012); see also Erik Voeten, International Courts Data, http://www9. georgetown.edu/faculty/ev42/ICdata.htm.

3 Int'l Courts \& Tribunals Series, Oxford UnIV. Press, http://ukcatalogue.oup. com/category/academic/series/law/icts.do\#.UArFnvk0WSp (last visited Jan. 30, 2013); The Oxford Handbook of International Adjudication (Cesare P. Romano, Karen J. Alter \& Yuval Shany eds., forthcoming 2013).

4 LAW \& Practice InT'L Cts. \& TRiBunALs, http://booksandjournals.brillonline. com/content/15718034 (last visited Apr. 17, 2013).

5 E.g., iCourts: The Danish Nat'l Research Foundation's Ctr. of Excellence for INT'L COURTS, http://jura.ku.dk/icourts (last visited Apr. 17, 2013); ERC PROJECT on EfFECTIVE InT'L AdJUdiCATION, http://www.effective-intl-adjudication.org (last visited Apr. 17, 2013); MultiRights: The Legitimacy of Multi-Level Human Rights Judiciary, http://www.jus.uio.no/english/research/projects/multirights (last visited Apr. 17, 2013).

6 E.g., Special Issue: Legitimacy and the Future of the European Court of Human Rights, 12 German L.J. 1707 (2011); Armin von Bogdandy \& Ingo Venzke, Beyond Dispute: International Judicial Institutions as Lawmakers, 12 GERMAN L.J. 979 (2011); David D. Caron, Towards a Political Theory of International 
The growing political salience of IC rulings has generated increased scrutiny of the legitimacy of ICs. As international judges adjudicate a widening array of controversies, they must inevitably clarify the meaning of ambiguous international rules and apply them to unforeseen contexts. They may also go further, using teleological methods of interpretation to broaden the reach of international law, expanding the types of actors who can file complaints, and awarding creative remedies that make legal rights more meaningful. The cumulative result of these trends is an expansion of IC authority and influence and a concomitant diminution of national autonomy.

This Article explores the relationship between the legitimacy of ICs and expansive judicial lawmaking. ${ }^{7}$ Most of the existing literature focuses on legitimacy or on lawmaking, but does not directly consider the relationship between them. One group of studies argues that ICs operate within a strategic space - a zone of law that is bounded and mediated by politics. ${ }^{8}$ Another reveals that ICs that enjoy diffuse support have more room to issue controversial rulings that are unpopular with governments and to withstand the political opposition and resistance that such rulings often generate. ${ }^{9}$ Yet we have little empirical evidence to assess how an IC's legitimacy affects its penchant for lawmaking, and vice versa.

In this Article, we question the oft-voiced conventional wisdom that expansive judicial lawmaking undermines judicial legitimacy. We do so by comparing the evolution of three ICs situated, respectively, in Europe (the Court of Justice of the European Union (CJEU)), Latin America (Tribunal

Courts and Tribunals, 24 Berkeley J. Int'L L. 401 (2006); Rachel Cichowski, Courts, Democracy and Governance, 39 Comp. Pol. Stud. 3 (2006); Kanstantsin Dzehtsiarou \& Alan Greene, Legitimacy and the Future of the European Court of Human Rights, 12 German L.J. 1707 (2011).

7 For definitions of these terms, see infra Section I.A.

8 E.g., Richard H. Steinberg, Judicial Lawmaking at the WTO: Discursive, Constitutional, and Political Constraints, 98 Am. J. INT'L L. 247 (2004); see also Laurence R. Helfer, Why States Create International Tribunals: A Theory of Constrained Independence, in InTERnATIONAL Conflict Resolution 255 (Stefan Voigt et al. eds., 2006).

9 James Gibson \& Gregory Caldeira, The Legitimacy of Transnational Legal Institutions: Compliance, Support, and the European Court of Justice, 39 Aм. J. Pol. ScI. 459, 471 (1995) [hereinafter Gibson \& Caldeira, ECJ Legitimacy] (defining diffuse support "as institutional commitment — that is, willingness to defend the [judicial] institution against structural and functional alterations that would fundamentally alter the role of the institution in society"); see also James Gibson \& Gregory Caldeira, Changes in the Legitimacy of the European Court of Justice: A Post-Maastricht Analysis, 28 BRit. J. Pol. SCI. 63 (1993). 
of Justice of the Andean Community (ATJ or the Tribunal)), and Africa (the Economic Community of West African States Community Court of Justice (ECCJ or the ECOWAS Court)). These ICs, which are all part of regional integration initiatives, have similar jurisdictional grants, access rules, and links to domestic courts. Each court reviews complaints from private litigants, governments, and supranational bodies, and each can receive preliminary references from national judges. The three ICs were also created for similar reasons: to provide a judicial venue for interpreting international rules and settling disputes relating to regional integration. Yet each court has behaved in a strikingly different way when faced with opportunities to engage in expansive judicial lawmaking.

Judges on the CJEU are well known for boldly applying teleological methods of interpretation to expand the scope of E.U. law and their own power as the final arbiters of that law's meaning. In Latin America, although Andean governments copied the CJEU's design features, ATJ judges have eschewed opportunities to broadly construe their authority and to adopt purposive interpretations to advance regional integration. In West Africa, judges on the ECCJ followed yet a different path. When asked to hear a suit from a private litigant, the judges expressly declined to follow the CJEU's activist approach and dismissed the case. Outside of the courtroom, however, ECCJ judges launched a successful advocacy campaign to convince ECOWAS member states to expand its jurisdiction and access rules.

These divergent strategies and their outcomes are at odds with the conventional wisdom described above. The most expansive IC - the CJEU - faces occasional legitimacy challenges, but its famously expansive doctrines, such as the direct effect and supremacy of European law and implied powers for E.U. institutions, have been fully assimilated as part of the court's legitimate authority. In contrast, the ATJ's careful attention to its jurisdictional mandate has avoided serious challenges from Andean governments, but it has also relegated the Tribunal to a mostly politically marginal role. And the fact that the ECCJ obtained formal approval from states for expanding its jurisdiction has not shielded the court from government opposition to its rulings.

This pattern suggests that there is no inherent relationship between expansive judicial lawmaking and challenges to IC legitimacy. The evidence is also consistent with an alternative hypothesis - that ICs trigger legitimacy challenges due to the domestic political impact of their decisions, regardless of whether those decisions are expansionist. Our modest goal in this Article, however, is not to develop an affirmative theory of international judicial legitimacy. Rather, we seek to problematize the putative link between lawmaking and legitimacy implied by public critiques of ICs and sometimes by scholars, and to offer this alternative hypothesis as a conjecture for future research. 
The remainder of this Article proceeds as follows. Part I provides an overview of the relationship between IC legitimacy and judicial lawmaking, drawing on a range of recent studies and examples. Part II, which builds on our previous publications and works in progress, describes the lawmaking strategies of three community courts: the CJEU, the ATJ, and the ECCJ. Part III concludes by positing that it is the domestic impact of a court's decisions, rather than the extent of judicial lawmaking, that shapes political responses to ICs.

\section{The Relationship Between Legitimacy and LaWMaking BY InTERnational COURTS}

The growing number of complaints filed with ICs around the world presents numerous opportunities for international judges to extend the reach of international law and their own review powers. Critics of ICs suggest that judges will inevitably seek to expand their power and reach, and that these expansions will inevitably compromise the courts' legitimacy. We first explain our contrary view that expansive judicial lawmaking is not inherently linked to legitimacy. We then identify two types of lawmaking that are the most likely to raise legitimacy concerns.

\section{A. Decoupling Legitimacy from Judicial Lawmaking}

We adopt Nienke Grossman's basic definition of "legitimate" ICs as those "whose authority is perceived as justified." 10 We also agree with James Gibson and Gregory Caldeira that legitimacy "provides courts authority; it allows them the latitude necessary to make decisions contrary to the perceived immediate interests of their constituents. Since courts typically have neither the power of the 'purse nor the sword,' this moral authority is essential to judicial effectiveness." 11 Factors that influence an IC's legitimacy include "the fair and unbiased nature of the adjudicative body, commitment to the underlying normative regime that the body is interpreting and applying, and the body's transparency and relationship with other democratic values."12 These analyses of IC legitimacy do not directly address judicial lawmaking.

10 Nienke Grossman, Legitimacy and International Adjudicative Bodies, 41 Geo. Wash. InT'L L. Rev. 107, 110 (2009) (citing Daniel Bodansky, The Legitimacy of International Governance: A Coming Challenge for International Environmental Law?, 93 Aм. J. InT'L L. 596, 600 (1999)).

11 Gibson \& Caldeira, ECJ Legitimacy, supra note 9, at 460.

12 Grossman, supra note 10, at 110; see also Andreas Follesdal, The Legitimacy Deficits of the Human Rights Judiciary: Elements and Implications of a Normative 
Their silence implicitly reflects the widespread recognition that some degree of lawmaking - including activities such as "developing, adapting, modifying, filling gaps, interpreting, or even branching out in a new direction"13 — is an inevitable part of judging and thus a legitimate judicial function. Many treaties are the international equivalent of incomplete contracts, and judges often cannot avoid clarifying ambiguities or filling gaps in their texts. ${ }^{14}$ As the German Federal Constitutional Court recently asserted, judicial lawmaking is an inherent function of ICs that is "particularly warranted when it 'concretizes programs' (in the sense that it implements the normative project of a treaty), when it fills in legal gaps and when it solves contradictions." 15

Yet there is also a broadly shared expectation that ICs that extend their jurisdiction or review powers beyond the boundaries imposed by states are likely to generate political frictions or backlashes. ${ }^{16}$ Some critics of ICs go further, arguing that such expansions necessarily undermine a court's legitimacy by usurping the power of lawmaking bodies or transgressing the outer limits of delegated authority. ${ }^{17}$ Even national judges who accept the need for modest

Theory, 14 Theoretical InquiRIEs L. 339, 345-46 (2013) (developing a taxonomy of different types of IC legitimacy).

13 Mohamed Shahabuddeen, Precedent in the World Court 91 (2007) (quoting ICJ Judge Sir Robert Jennings); see also Tom Ginsburg, Bounded Discretion in International Judicial Lawmaking, 43 VA. J. INT'L L. 631, 639 (2005) ("[I]nternational judges also frequently make law in the course of declarations pertaining to the existing law").

14 E.g., Eyal Benvenisti, The Interplay Between Actors as a Determinant of the Evolution of Administrative Law in International Institutions, 68 LAW \& CONTEMP. Probs. 319 (2005); Joel P. Trachtman, The Domain of WTO Dispute Resolution, 40 HaRV. INT'L L.J. 333 (1999).

15 Armin von Bogdandy \& Ingo Venzke, On the Democratic Legitimation of International Judicial Lawmaking, 12 GERMAN L.J. 1341, 1345 (2011) (paraphrasing Bundesverfassungsgericht [BVerfG] [Federal Constitutional Court] July 6, 2010, docket no. 2 BvR 2661/06, ๆ 64 , available at http://www. bverfg.de/entscheidungen/rs20100706_2bvr266106en.html, which considered a constitutional challenge to the CJEU's Mangold judgment).

16 E.g., Eric Posner \& John Yoo, Judicial Independence in International Tribunals, 93 CALIF. L. REv. 1, 21 (2005) ("If the tribunal violates its instructions and allows the personal preferences, ideological commitments, or national loyalties of its members to influence the judgment too much, then compliance might not occur").

17 E.g., Robert H. Bork, Coercing Virtue: The Worldwide Rule of Judges (2003); Eric A. Posner, The Perils of Global Legalism (2009); Jeremy A. Rabkin, Law Without Nations? Why Constitutional Government Requires Sovereign STATES (2005). 
lawmaking by international judges assert that an IC acts ultra vires when it "goes against what is clearly stated in the text, or when it creates new rights or obligations without sufficient justification in the relevant positive law."18

A recent special issue of the German Law Journal explores these issues in greater depth. The contributions to this symposium link judicial lawmaking to various critiques that have been leveled against ICs, such as their contribution to democratic deficits or the fragmentation of international law. The studies suggest a transitive relationship whereby the association of expansive lawmaking with one or more of these critiques implies, syllogistically, that lawmaking itself undermines IC legitimacy. ${ }^{19}$

We argue, to the contrary, that expansive judicial lawmaking is neither a necessary nor a sufficient condition for triggering challenges to IC legitimacy by powerful domestic actors. A court can engender such challenges simply by exercising the review functions that states have expressly and unambiguously delegated to it. Conversely, a court may, under the right conditions, boldly expand its power and receive a supportive or even laudatory response from governments.

Examples of the first situation - challenges to an IC that acts scrupulously within its mandate - are sadly common for human rights tribunals. States voluntarily accept international review mechanisms when they ratify human rights treaties or accept optional complaints procedures; indeed, the whole point of tasking human rights tribunals with oversight powers is to hold governments accountable to their international pledges to respect individual liberties. ${ }^{20}$ Yet when the tribunals exercise these expressly delegated review powers, governments sometimes respond by contesting their legitimacy. For example, as we later explain in greater detail, ECOWAS member states expressly authorized the ECCJ to review complaints from private litigants alleging violations of their human rights. Yet when the court received credible evidence of arbitrary detention and torture by security forces in Gambia, the state argued that the ECCJ's exercise of jurisdiction was "an affront to [its] sovereignty." 21

18 Von Bogdandy \& Venzke, supra note 15, at 1345 (paraphrasing docket no. 2 BvR 2661/06, $\uparrow 105$, in which the German Federal Constitutional Court concluded that the CJEU, in a 2005 judgment, had "manifestly transgressed the competences granted to it to interpret Community law ... and acted ultra vires").

19 E.g., von Bogdandy \& Venzke, supra note 15, at 1368 ("Our introductory piece has identified problems in the democratic legitimation of international judicial lawmaking. Our concluding contribution shows that there are promising strategies to respond, but that no solutions are readily available to ease all concerns.").

20 AlTER, supra note 1, ch. 2.

21 Musa Saidykhan v. Republic of the Gambia, ECW/CCJ/RUL/05/09 \ 11 (Interim 
The second situation - a court that expands its authority with the support or acquiescence of states - occurs where governments and other influential domestic actors develop a preference for stronger judicial review after an IC has been established. Later, we discuss the CJEU's expansion of its own authority to review human rights claims, an enlargement that E.U. member states subsequently endorsed. ${ }^{22}$ Another example is the European Court of Human Rights (ECtHR)'s pilot judgment procedure, a judicial innovation for efficiently resolving hundreds or even thousands of complaints challenging the same human rights violations. ${ }^{23}$ Commentators widely view the pilot judgment procedure as successful, both in inducing governments to resolve systemic human rights violations and in helping the ECtHR to reduce its backlog of pending cases. But they also agree that the court has no formal authority to create the procedure..$^{24}$ Rather, the legitimacy of the court's initial adoption of these practices stemmed from a vague, nonbinding resolution of the Council of Europe's Committee of Ministers, ${ }^{25}$ and from the "consensual subsequent practice of the state parties." 26

\section{B. Where Judicial Lawmaking Raises Legitimacy Concerns}

Some judge-made augmentations of authority may engender political controversies and thus call a court's legitimacy into question. We define such expansive lawmaking as occurring when ICs "identify new legal obligations or constraints not found in treaty texts or supported by the intentions of their drafters, and when these obligations or constraints narrow states' discretion." 27 Two types of expansionist lawmaking are especially likely to raise legitimacy

Ruling of June 30, 2009) (on file with authors) (quoting government's preliminary objection).

22 See infra Section III.A.

23 See, e.g., Antoine Buyse, The Pilot Judgment Procedure at the European Court of Human Rights: Possibilities and Challenges, 57 Noміко Viмa 1890 (2009); Markus Fyrnys, Expanding Competences by Judicial Lawmaking: The Pilot Judgment Procedure of the European Court of Human Rights, 12 German L.J. 1231 (2011).

24 Fyrnys, supra note 23, at 1251-53.

25 Council of Europe, Resolution (2004)3 of the Committee of Ministers on Judgments Revealing an Underlying Systemic Problem (May 12, 2004), available at https://wcd.coe.int/ViewDoc.jsp?id=743257\&Lang=en.

26 Fyrnys, supra note 23, at 1252.

27 Karen J. Alter \& Laurence R. Helfer, Nature or Nurture? Judicial Law-Making in the European Court of Justice and the Andean Tribunal of Justice, 64 INT'L ORG. 563, 566 (2010). 
concerns - the use of aggressively teleological or purposive methods of treaty interpretation, and the expansion of an IC's mandate to encompass subject areas that states have not expressly delegated to it.

Many international agreements lay out general principles that states expect to be filled in later in various ways, including by the adoption of supplementary texts, reference to the practices of treaty parties, and interpretation by ICs. When judges fill in details that have been left unspecified, their lawmaking is generally uncontroversial. Yet litigants sometimes ask ICs to use interpretation to achieve bolder aims, such as augmenting existing rules to substitute for missing secondary legislation, converting nonbinding declarations of intent into binding and enforceable obligations, or conferring a quasi-constitutional status on certain treaty provisions. ${ }^{28}$ These litigant demands force ICs to confront tough political choices. Judges must determine how fast and how far states are willing to move toward achieving a legal regime's broad goals, and to what extent they narrow state discretion or push states to realize those goals.

In Europe, the CJEU declared that certain commitments in the Treaty of Rome ${ }^{29}$ had direct effect in national legal orders, and it interpreted those commitments to catalyze integration when political support for the E.U. project had stalled. ${ }^{30}$ Yet the CJEU was acutely aware that its aggressive lawmaking created a risk of backlash from governments and national judges. To reduce this risk, the court used the E.U. Commission "as a political bellwether, watching its position on major cases as a sign of what the political traffic [would] bear." "31 It also introduced new pro-integration legal doctrines gradually and with qualifications. "If there [we]re not too many protests," these judicial innovations were "re-affirmed in later cases; the qualifications . . . whittled away and the full extent of the doctrine[s] revealed." 32 Even with these cautious maneuvers, however, the court occasionally misjudged the political landscape and provoked efforts to reverse or qualify expansive CJEU rulings. ${ }^{33}$

28 ICs that act in these ways are often accused of judicial "activism," a term that critics often use as a conclusory epithet to attack decisions that they disfavor. E.g., Neil S. Siegel, Interring the Rhetoric of Judicial Activism, 59 DePaul L. REV. 555 (2010). For a recent discussion of activism by ICs, see Fuad Zarbiyev, Judicial Activism in International Law - A Conceptual Framework for Analysis, 3 J. Int'L Disp. Settlement 247 (2012).

29 Treaty Establishing the European Economic Community, Mar. 25, 1957, 298 U.N.T.S. 11 (1958) [hereinafter Treaty of Rome].

30 E.g., Joseph Weiler, The Community System: The Dual Character of Supranationalism, 1 Y.B. Eur. LAw 257 (1981).

31 Helfer \& Slaughter, supra note 1, at 315.

32 Trevor Hartley, The Foundations of European Community Law 78-79 (1994).

33 Karen J. Alter, The European Union's Legal System and Domestic Policy: 
Legitimacy concerns can also arise when ICs extend their mandates beyond the unambiguous limits prescribed by governments. A prominent illustration relates to sub-regional courts in Africa. The treaty establishing the East African Community Court of Justice (EACJ) expressly excludes human rights and contemplates the later adoption of a protocol to extend the court's jurisdiction to human rights cases. ${ }^{34}$ To date, however, such a protocol has not been adopted, leading commentators — and the court itself — to conclude that that the EACJ "has no jurisdiction where infringements that occur relate ... to the human or other individual rights of the residents." ${ }^{35}$ Nevertheless, since 2007 the EACJ has decided that it would "not abdicate from exercising its jurisdiction of interpretation under [the EAC Treaty] merely because [a complaint] includes allegations of human rights violation[s]"36 — in effect reaching the same result through a purposive interpretation of the treaty.

These decisions - as well as recent human rights decisions from the Southern African Development Community (SADC) Tribunal ${ }^{37}$ — have been criticized as "nothing short of extreme judicial activism, skewed towards a usurpation of legislative functions." ${ }^{38}$ East African Community (EAC) member

Spillover or Backlash?, in The European Court's Political Power: Selected EsSAYS 184 (2009).

34 Solomon T. Ebobrah, Litigating Human Rights Before Sub-Regional Courts in Africa: Prospects and Challenges, 17 Afr. J. InT'L \& Comp. L. 79, 82 (2009).

35 T.O. Ojienda, The East African Court of Justice in the Re-established East Africa Community: Institutional Structure and Function in the Integration Process, 11 E. Afr. J. Peace \& Hum. Rts. 220, 228 (2005).

36 James Katabazi v. Sec'y Gen. of the E. Afr. Cmty. (E. Afr. Ct. of Just., Nov. 1, 2007), available at http://www.eacj.org/docs/judgements/JUDGMENT_ REFERENCE_NO._1_OF_2007.pdf.

37 Solomon T. Ebobrah, Human Rights Developments in African Sub-Regional Economic Communities During 2010, 11 Afr. Hum. RTs. J. 216, 246 (2011):

While no express human rights competence is conferred on the [SADC] Tribunal, since 2007 the Tribunal has understood its power to interpret and apply the SADC Treaty as sufficient to adjudicate on claims that human rights have been violated in an SADC member state contrary to the provisions of the SADC Treaty.

38 Lucyline Nkatha Murungi \& Jacqui Gallinetti, The Role of Sub-Regional Courts in the African Human Rights System, 7 InT'L J. Hum. RTs. 119, 133 (2010). The controversy stems from Tribunal decisions that challenged President Robert Mugabe's postcolonial land redistribution policies seizing land from white farmers. See Precious N. Ndlovu, Campbell v. Republic of Zimbabwe: A Moment of Truth for the SADC Tribunal, 1 SADC L.J. 63 (2011); Mwiza Jo Nkhata, The Role of Regional Economic Communities in Protecting and Promoting Human Rights in Africa: Reflections on the Human Rights Mandate of the Tribunal of 
states have opposed the EACJ's assertion of a human rights competence in pleadings before the court. But they have not — at least not yet — challenged that competence politically. ${ }^{39}$ The SADC Tribunal, in contrast, has experienced an intense backlash from member countries in the form of a suspension of the court's operations in 2011 and the adoption in 2012 of a new protocol that removes access by private litigants - moves widely seen as ending the Tribunal's power to review challenges to member states' human rights practices. ${ }^{40}$

Taken together, these examples suggest that certain types of expansive IC lawmaking — in particular, the use of aggressively teleological interpretive methods or the expansion of subject matter competencies - sometimes trigger legitimacy challenges. But the examples do not support the broader proposition that expansive judicial lawmaking is a necessary or a sufficient condition for such challenges. To the contrary, as we now illustrate, even ICs with similar design features have adopted widely divergent approaches to judicial lawmaking, engendering responses by states that range from endorsement to acquiescence to opposition.

\section{The Divergent Lawmaking Strategies of the CJEU, THE ATJ, AND THE ECCJ}

This Part summarizes the divergent approaches to judicial lawmaking by three international courts - the CJEU, the ATJ, and the ECCJ. Although these courts operate in different legal, political, and institutional contexts, their divergent lawmaking strategies are especially striking given that the three

the Southern African Development Community, 20 Afr. J. InT'L \& Comp. L. 87 (2012).

39 In late 2006, in response to a ruling by the EACJ, the member states amended the EAC Treaty to create an appellate division of the EACJ, impose time limits on private actors filing suits with the court, and add new grounds for removing and suspending judges. Henry Onoria, Botched-Up Elections, Treaty Amendments and Judicial Independence in the East African Community, 54 J. Afr. L. 74, 83 (2010). These amendments became effective before the EACJ adopted a purposive interpretation of the EAC Treaty relating to human rights. The relationship, if any, between the amendments and the court's human rights case law remains to be explored.

40 Press release, allAfrica, SADC Leaders Deal Fatal Blow to SADC Tribunal Shock Decision Denies Citizens Access to the Court (Aug. 20, 2012), available at http://allafrica.com/stories/201208200629.html. For further discussion, see Nkhata, supra note 38, at 96-109; Werner Scholtz, Review of the Role, Functions and Terms of Reference of the SADC Tribunal, 1 SADC L.J. 197, 197-201 (2011). 
courts' jurisdictions and access rules are very similar, and that the ATJ and the ECCJ were modeled on the CJEU. These differences suggest that copying the design features of an IC that engages in expansive lawmaking does not necessarily copy that court's penchant for finding new legal obligations or narrowing state discretion.

\section{A. CJEU: Using Expansive Lawmaking Aggressively to Promote Integration}

When the CJEU was established in the 1950s, its judgments were binding under international law, but the court had no way to enforce its decisions or to penetrate national legal orders. Over the ensuing forty years, however, the CJEU transformed the Treaty of Rome ${ }^{41}$ and secondary legislation into legal rules that are directly enforceable in cases filed by private litigants in domestic courts. The CJEU's foundational doctrines declaring European law's direct domestic effect, its supremacy over national law, and its preemptive power were created not by the treaty's drafters but by the court itself. Other CJEU innovations included implied powers for supranational lawmaking and the development of a human rights jurisprudence to check potential excesses of E.U. institutions. ${ }^{42}$ Perhaps most remarkably, each of these doctrines - and the CJEU's authority to articulate and extend them — were ultimately embraced by national judiciaries across Europe. ${ }^{43}$

The CJEU justified these doctrinal innovations as necessary to give effect to the Treaty of Rome. ${ }^{44}$ The CJEU's expansions have been widely hailed

41 Treaty of Rome, supra note 29.

42 Joseph H.H. Weiler, The Transformation of Europe, 100 YALE L.J. 2403 (1991).

43 This discussion builds on an extensive body of research on the CJEU. Readers interested in more detailed analysis should consult publications including: KAREN J. Alter, Establishing the Supremacy of European Law: The Making of a Rule of Law in Europe (2001); The European Courts and National Courts: Doctrine AND Jurisprudence (Anne-Marie Slaughter, Alec Stone-Sweet \& Joseph Weiler eds., 1998).

44 CJEU judge Pierre Pescatore has cogently written of these innovations:

This philosophy is very simple indeed. It means that legal rules, by their very nature, have a practical purpose. Any legal rule is devised so as to operate effectively (we are accustomed, in French, to speak here about effet utile). If it is inoperative, it is not a rule of law. The task of lawyers is therefore not to thwart effects of legal rules, but to help in putting them into operation. In other words, practical operation for all concerned, which is nothing else than "direct effect," must be considered as being the normal condition of any rule of law.

Pierre Pescatore, The Doctrine of "Direct Effect": An Infant Disease of Community Law, 8 Eur. L. REv. 155, 155 (1983). 
as advancing integration through law when political support for a European common market had faltered. The court is credited with transforming the Treaty of Rome from a traditional instrument of public international law into a constitutional charter for regional integration. ${ }^{45}$

Although the CJEU used the language of the law to justify its purposive interpretations, the judges also acknowledged that they realized these achievements by carefully nurturing relationships with stakeholders who favored the court's bold maneuvers. CJEU judges and members of the Commission's legal secretariat regularly participated in events for scholars and practitioners of E.U. law. The court invited national judges to Luxembourg to discuss European legal issues and share in fine dining. These outreach efforts were designed to encourage preliminary references, a mechanism that enabled domestic courts to seek the CJEU's guidance as to the meaning of European law. ${ }^{46}$

Spurred by requests from private litigants who benefitted from E.U. rules, national judges, lawyers, and scholars became the CJEU's primary interlocutors and compliance partners. As judges referred a growing number of cases, they became habituated to following CJEU preliminary rulings and to adjudicating the treaty-compatibility of domestic laws. With European rules woven into the fabric of national judicial rulings, governments could not defy the CJEU without also calling into question the independence and authority of their own courts. As Joseph Weiler has explained, "[w]hen a national court accepts the [CJEU's] ruling, the compliance pull of Community law becomes formidable." ${ }^{\prime 4}$

Inasmuch as judges at all levels of national legal systems can seek preliminary rulings, individuals and firms have had access to multiple venues in which to pursue E.U. litigation, and the CJEU has had numerous opportunities to develop and refine the content of European rules. The interaction between CJEU judges and their domestic colleagues has shaped the scope and substance of

45 E.g., G. Federico Mancini, The Making of a Constitution for Europe, 26 Common Mкт. L. Rev. 595, 605 (1989); Eric Stein, Lawyers, Judges and the Making of a Transnational Constitution, 75 Am. J. INT'L L. 1 (1981).

46 As CJEU judge G. Federico Mancini has explained, the "Court's first preoccupation" was to win the "co-operation and goodwill of the state courts." Mancini, supra note 45, at 605. The CJEU's outreach efforts are discussed in KAREN ALTER, Jurist Advocacy Movements in Europe: The Role of Euro-Law Association in European Integration (1953-1975), in The European CourT's Political Power: Selected Essays, supra note 33, at 63, 65-72.

47 Joseph Weiler, A Quiet Revolution: The European Court of Justice and Its Interlocutors, 26 Comp. Pol. STUD. 510, 519 (1994). For further discussion, see Karen Alter, Who Are the 'Masters of the Treaty'?: European Governments and the European Court of Justice, in The European Court's Political Power: Selected Essays, supra note 33, at 109, 117-23. 
European law, leading to extensions of legal rules regulating the free movement of goods, gender equality, environmental protection and human rights. ${ }^{48}$

It is instructive to contrast the CJEU's expansion into human rights with the previous discussion of the EACJ and SADC Tribunal. As Weiler has explained, the Treaty of Rome did not include a bill of rights and did not authorize the CJEU to hear suits alleging human rights violations. Weiler saw the CJEU's decision to extend its competence to human rights issues as a reflection of its pretensions to be a constitutional tribunal. He recognized, however, that national judges supported - even demanded - this doctrinal evolution. ${ }^{49}$ More recent scholarship links these developments to unresolved political debates that later spilled over into litigation. According to Gráinne de Búrca, German negotiators tried but failed to insert human rights into the E.U. treaties. Litigants then raised human rights claims in German courts. When these cases reached the CJEU, the judges at first refused to embrace human rights review. De Búrca explains the CJEU's subsequent "volte face" as necessary to support the supremacy of European law and to rebuff "claims that Community law must be subordinate to national constitutional rights." ${ }^{50}$ Member states later enshrined the CJEU's lawmaking into European legal texts, formally delegating to the court an express human rights competence. ${ }^{51}$

There have also been debates in Southern and East Africa about the legality and wisdom of regional courts embracing human rights. Yet as previously described, the reaction has been strikingly different than in Europe, leading governments to narrow or abrogate private litigants' access to the tribunals in those regions. ${ }^{52}$ There are several possible explanations for these divergent responses. First, unlike in Africa, the CJEU reluctantly expanded its human rights authority in response to demands from important domestic compliance partners - national courts. In addition, the ECJ's human rights review was initially confined to E.U. institutions and did not extend to national governments. Third, early CJEU human rights cases focused on legal issues that were closely linked to regional integration. ${ }^{53}$

48 Alec Stone Sweet, The Judicial Construction of Europe (2004); Gráinne de Búrca, Roads Not Taken: The EU as a Global Human Rights Actor, 105 Ам. J. INT'L L. 649, 665-68 (2011).

49 Weiler, supra note 42, at 2417 ("[E]ven if protection of human rights per se need not be indispensable to fashioning a federal-type constitution, it was critical to the acceptance by courts in the Member States").

50 De Búrca, supra note 48, at 668.

51 Id. at 687.

52 See supra Section I.B.

53 De Búrca, supra note 48, at 667-70. De Búrca charts the expansion of the CJEU's human rights jurisprudence following the Maastricht Treaty, id. at 670-73. 
The CJEU's aggressive bolstering of European integration and enlarging of E.U. law has not been without missteps. There have been a range of challenges by governments to particular expansive applications of existing doctrines, but these have been episodic and usually focused on the outcomes of specific cases. ${ }^{54}$ Despite these concerns, member states have repeatedly expanded the court's jurisdiction - in 1988, by creating the Tribunal of First Instance (now the General Court); in 1993, by authorizing financial sanctions for noncompliance with CJEU rulings; and in the 2009 Lisbon Treaty, by giving the court jurisdiction over certain justice and home affairs issues. ${ }^{55}$ The result, on balance, has been an implicit affirmation by European governments of the CJEU's doctrinal innovations and their associated expansions of the court's authority.

\section{B. The ATJ: Deference to Member States, Except for Intellectual Property Issues $^{56}$}

The Andean Pact, a South American regional integration initiative launched in 1969, initially did not include a community court. When member states decided to create a judicial body to interpret and help enforce Andean rules,

54 Alter, supra note 46, at 128-32. For a debate about member state reversals of ECJ decisions, see Mark Pollack, The Engines of Integration: Delegation, Agency, and Agency Setting in the European Union ch. 2 (2003); Geoffrey Garrett et al., The European Court of Justice, National Governments and Legal Integration in the European Union, 52 INT'L ORG. 149 (1998).

55 De Búrca, supra note 48, at 649. The Treaty of Amsterdam included provisions granting the E.U. competence over certain justice and home affairs issues. The Lisbon Treaty made a number of additional changes to these competences, including the greater involvement of the CJEU. See Elizabeth F. Defei, Human Rights, the European Union, and the Treaty Route: From Maastricht to Lisbon, 35 Fordham InT'L L.J. 1207 (2012).

56 The discussion in this Section builds on our previously published research on the Andean legal system. Readers interested in more detailed analysis should refer to the following publications: Alter \& Helfer, supra note 27; Karen J. Alter \& Laurence R. Helfer, Legal Integration in the Andes: Law-Making by the Andean Tribunal of Justice, 17 Eur. L.J. 701 (2011); Karen J. Alter, Laurence R. Helfer \& Osvaldo Saldias, Transplanting the European Court of Justice: The Experience of the Andean Tribunal of Justice, 60 Aм. J. CoмP. L. 629 (2012); Laurence R. Helfer \& Karen J. Alter, The Andean Tribunal of Justice and Its Interlocutors: Understanding the Preliminary Ruling Reference Patterns in the Andean Community, 42 N.Y.U. J. INT'L \& PoL. 871 (2009) [hereinafter Helfer \& Alter, Interlocutors]; Laurence R. Helfer, Karen J. Alter \& Maria Florencia Guerzovich, Islands of Effective International Adjudication: Constructing an 
they looked to Europe for guidance. The ATJ, which began operations in 1984 , is a close copy of the CJEU. It has very similar jurisdictional provisions and access rules, including a preliminary reference mechanism. The ATJ's founders were also aware of key doctrines that the CJEU had developed to promote European integration.

When the Andean Tribunal first began to hear cases in 1987, it emulated CJEU jurisprudence. Early ATJ rulings confirmed key E.U. doctrines - that Andean law had direct effect and supremacy over national law, and preempted conflicting domestic legislation. Whereas European judges had created these doctrines themselves, the ATJ suggested that member states had implicitly endorsed them. ${ }^{57}$

When it came to applying these doctrines, however, Andean judges diverged from the CJEU in several significant respects. The ATJ declined to serve as an engine of Andean integration. Formally, the ATJ views the Cartagena Agreement $^{58}$ — the treaty that established the Andean Community — as higherorder law. But the Tribunal has also emphasized that the Andean legal order is a product of member state consent. And it has scrupulously respected that consent when interpreting the treaty and Andean secondary legislation. ${ }^{59}$ The ATJ's deferential review of government decisions gives political leaders wide discretion to control the scope and pace of integration to reflect the waxing and waning of their collective commitment to creating a common market. ${ }^{60}$

ATJ judges have also avoided the purposive interpretations that are the CJEU's hallmark, ${ }^{61}$ rejecting the pleas of private litigants to imply legal rights and obligations from the structure of the community legal system. As compared to the CJEU, the ATJ has given governments far greater leeway to adopt national laws in areas of community competence, and it has refused to imply powers for Andean institutions. For example, the ATJ announced the principle of complemento indispensable: even in areas where Andean law clearly governs, member states may enact domestic laws necessary to implement a community rule provided that the laws do not obstruct or nullify the community rule. ${ }^{62}$ In addition, when responding to requests for preliminary

Intellectual Property Rule of Law in the Andean Community, 103 Am. J. INT'L L. 1 (2009).

57 Alter \& Helfer, supra note 27, at 571.

58 Andean Subregional Integration Agreement, May 26, 1969, 8 I.L.M. 910.

59 For example, the ATJ refused to elevate the Cartagena Agreement over Andean legislation that permitted governments to exempt goods on a list of exceptions to free trade rules. Alter \& Helfer, supra note 27, at 572.

60 Id. at 579.

61 Pescatore, supra note 44, at 155.

62 Alter \& Helfer, supra note 27, at 571. 
rulings, the Tribunal generally explicates the meaning of Andean law in the abstract without applying that law to the facts of the case or giving more than nominal guidance as to how national judges should resolve the dispute.

We attribute the ATJ's reticence to the judges' understanding that they lack the deep political and legal support needed to promote legal integration more aggressively. Local demand for integration is generally weak, reflecting the fact that intraregional trade is far less important to Andean countries than trade with non-member countries. With less at stake economically, private litigants have filed only a modest number of challenges to national laws or regulations that conflict with Andean rules. And national judges have generally refrained from invaliding such laws even when the violation of community law is manifest. Lacking a domestic constituency that favors expansive judicial lawmaking, the ATJ has proceeded cautiously. This approach has avoided direct clashes with governments, but it has also rendered the Tribunal far less relevant to the integration process than its European counterpart. ${ }^{63}$

However, in the one corner of the Andean legal system where the ATJ can count on strong domestic support, the Tribunal has been significantly bolder. Our previous studies reveal that the subject matter of ATJ preliminary rulings is highly concentrated - more than ninety-five percent involve challenges to decisions by domestic administrative agencies to grant or deny applications to register trademarks, patents and other intellectual property (IP) rights. ${ }^{64}$ This striking statistic underscores the extent to which domestic IP agencies in the Andes have acted as the ATJ's primary interlocutors.

Our research revealed that the agencies - which applied Andean IP rules to decide whether to register patents and trademarks - actively encouraged references to the ATJ and regularly consulted and applied the Tribunal's rulings. As we explain elsewhere, the agencies were reorganized in the 1990s as part of a wave of free-market reforms and were staffed by a professional cadre of foreign-trained lawyers. In addition, Andean IP law was a new and technical subject about which domestic actors had little knowledge. Agency administrators thus turned to the ATJ to help them address these complex issues. Over time, the Tribunal developed a symbiotic relationship with the agencies, responding to their requests for guidance and interpreting Andean IP rules in ways that reflected the practices and goals of agency administrators. ${ }^{65}$

Most ATJ IP decisions concern narrow issues with relatively low political salience. But a few noncompliance judgments have been more consequential. In these disputes, national actors initially followed domestic decrees that

63 Id. at 582-84.

64 Helfer \& Alter, Interlocutors, supra note 56, at 893-94.

65 Helfer, Alter \& Guerzovich, supra note 56, at 11-13, 22-24. 
conflicted with Andean IP rules. These actors changed course, however, after the ATJ ordered the agencies to comply with Andean law. The ATJ's rulings made it more difficult for member states to defect from community-wide standards in response to pressure from foreign governments to adopt stronger IP protection rules. Yet ATJ litigation has not spilled over to tariffs, taxes, customs or other subjects regulated by the community, primarily because the Tribunal lacks domestic interlocutors and compliance constituencies willing to file suits to enforce those regulations. The net result is that IP remains an island of effective international adjudication surrounded by a sea of Andean rules that are under-enforced and often circumvented by domestic actors. ${ }^{66}$

\section{The ECCJ: Building Legitimacy Through Publicity and Extrajudicial Advocacy $^{67}$}

The Economic Community of West African States (ECOWAS) followed an early trajectory similar to its predecessor in South America. When fifteen West African nations established ECOWAS in 1975, they emulated the E.U.'s political institutions but did not create a supranational court. ${ }^{68}$ The founders envisioned that a court would eventually be needed, ${ }^{69}$ but they did not act on this plan for more than fifteen years. A 1991 protocol established a blueprint for an international tribunal to interpret ECOWAS legal instruments in disputes between member states or between a member state and a community institution. ${ }^{70}$ However, the actual creation of the ECCJ and the appointment of its inaugural group of judges were delayed for another decade. And when the court finally opened its doors for business in 2001, the member states refrained from filing any cases, leaving the ECCJ with nothing to do.

The first suit to reach the ECCJ was filed in 2003 by a Nigerian goods trader, Olajide Afolabi, who challenged Nigeria's unilateral closure of its border

66 Id. at 26-30, 36-39.

67 This Section draws on our ongoing research on the ECOWAS legal system and the ECCJ, see Karen J. Alter, Laurence R. Helfer \& Jacqueline R. McAllister, A New International Human Rights Court for West Africa: The ECOWAS Community Court of Justice, 108 Aм. J. INT'L L. (forthcoming Oct. 2013), available at http://ssrn.com/abstract=2107427.

68 Treaty of the Economic Community of West African States (ECOWAS), May 28, 1975, 1010 U.N.T.S. 17, 14 I.L.M. 1200.

69 See id. arts. 11, 56.

70 Protocol A/P.1/7/91 on the Community Court of Justice, art. 9.3, July 7, 1991, available at http://www.afrimap.org/english/images/treaty/ECOWAS_Protocol_ Court_of_Justice.pdf, reprinted in Compendium of African Sub-Regional Human Rights Documents 194 (Solomon Ebobrah \& Armand Tanoh eds., 2010). 
with Benin. ${ }^{71}$ Afolabi claimed that the border closure violated ECOWAS rules guaranteeing the free movement of persons, goods, and capital, as well as a provision of the African Charter on Human and Peoples' Rights that protects the right to freedom of movement. Nigeria challenged the ECCJ's jurisdiction and Afolabi's standing to bring the suit. Afolabi countered by urging the ECCJ to adopt a purposive interpretation of the 1991 Protocol that would advance integration by granting individuals direct access to the ECCJ where their own government had violated ECOWAS rules. ${ }^{72}$

The judges acknowledged the case's sympathetic facts, which highlighted the serious barriers to intraregional trade in West Africa. ${ }^{73}$ Nevertheless, the court concluded that the 1991 Protocol was "unambiguous" on the issues of jurisdiction and standing,${ }^{74}$ and must therefore be "applied as written," even if the result - effectively insulating member states against suits by their own nationals - seemed "repugnant," "absurd[]" or "harsh."75 The ECCJ contrasted its interpretive approach with that of the CJEU, whose "activist[] judges" had "extend[ed] its review on jurisdiction to cover bodies which were not listed in the Treaty," and "fill[ed] in gaps in" European law. ${ }^{76}$ Noting that "some of the [CJEU's] decisions [have] attracted criticisms," the ECCJ candidly concluded: "We therefore do not want to tow on the same line."

The ECCJ's strict interpretation of the 1991 Protocol may seem surprising. Rather than deploy a purposive analysis to infer the power to adjudicate complaints from private litigants, the judges concluded that the ECOWAS member states must expressly confer such authority. Given the reluctance of West African governments to challenge each other's noncompliance with ECOWAS economic rules, ECCJ judges surely would have anticipated that their decision would result in a continued absence of cases from its docket.

Yet if the judges' interpretation of ECOWAS legal instruments was narrow and formalist, their behavior outside of the courtroom was strikingly different.

71 Olajide Afolabi v. Fed. Republic of Nigeria, ECW/CCJ/JUD/01/04 (Apr. 27, 2004), reprinted in 2004-2009 Смty. Ст. of Just., ECOWAS LaW Report 1 (2011).

72 Id. ๆๆ 14-15, 23, 41.

73 Id. 955.

$74 \quad$ Id. $\ 59$.

75 Id. $9 \uparrow 37,54$.

$76 \quad$ Id. $\ 56$.

77 Id. The ATJ also dismissed its first case — a suit by a private litigant — because the Cartagena Agreement did not expressly authorize such suits. But the ATJ also indicated that national courts (and, implicitly, preliminary references from those courts to the Andean Tribunal) were appropriate venues for private litigants to challenge violations of community law. 
On the same day in April 2004 that the ECCJ released the Afolabi decision, it issued a press release urging governments "to enable individuals to bring actions before the Court[,] as there are cases which Member States cannot bring on behalf of [their] nationals." ${ }^{" 78}$ As we explain elsewhere, during the next several months the judges traveled across West Africa to publicize the need for court reform in speeches and lectures. They also met with ECOWAS officials, civil society groups, and regional bar associations to plan a coordinated campaign to lobby governments to expand the court's jurisdiction and standing rules. The campaign succeeded..$^{79}$ Less than nine months after the ECCJ dismissed Afolabi's suit, the member states adopted the 2005 Supplementary Protocol. ${ }^{80}$ The Protocol significantly broadens the ECCJ's authority, most notably by granting individuals direct access to the ECCJ in cases alleging "the violation of human rights that occur in any member state." ${ }^{81}$

These expansions have recast the ECOWAS Court as an important new venue for human rights litigation in West Africa. Human rights advocates in the region are increasingly mobilizing around the court and including ECOWAS litigation in their advocacy strategies. As of March 2012, the ECCJ had issued forty-seven interim rulings and forty-five merits judgments, the vast majority of which address alleged violations of human rights treaties such as the African Charter. ${ }^{82}$

The ECOWAS Court has issued several high-profile decisions during the last few years, including against Gambia for the torture and disappearance of journalists, against Niger for condoning modern forms of slavery, and against Nigeria for failing to regulate multinational oil companies that polluted the

78 Lillian Okenwa, ECOWAS Court Not Open to Individual Litigants, THIS DAY (NIG.) (Apr. 28, 2004), http://www.accessmylibrary.com/coms2/ summary_0286-21180688_ITM.

79 Alter, Helfer \& McAllister, supra note 67.

80 Supplementary Protocol A/SP.1/01/05, Jan. 19, 2005, Amending Protocol A/P.1/7/91 relating to the Community Court of Justice, reprinted in CoMPENDIUM of African Sub-Regional Human Rights Documents, supra note 70, at 199.

81 Id. art. 3 (revising Article 9(4) of the 1991 Protocol). The 2005 Supplementary Protocol does not, however, authorize private litigants to file with the ECCJ complaints alleging violations of ECOWAS economic rules or challenges to domestic laws or practices that impede regional integration. We discuss the possible reasons for this omission in Alter, Helfer \& McAllister, supra note 67.

82 West Africa: ECOWAS Court Decides 92 Cases in Nine Years, LeAdERSHIP (Mar. 9, 2012), http://www.leadership.ng/nga/articles/18691/2012/03/09/ecowas court_decides_92_cases_9_years.html (reporting statement of the President of the ECCJ). 
Niger Delta and for curtailing funding for free basic education for all children. ${ }^{83}$ The ECCJ has also broadly construed the access provisions of the 2005 Supplementary Protocol to enable individuals, NGOs, and other private actors to bypass national courts and file suits directly with the ECCJ. ${ }^{84}$ At the same time, the court has dismissed complaints that raise novel legal theories, such as efforts to hold private actors responsible for human rights violations, and suits where plaintiffs failed to provide sufficient proof of alleged violations by governments. ${ }^{85}$ And after initially suggesting that it could review human rights claims relating to disputed elections, the ECCJ unequivocally declared that "no provision, whether general or specific, gives the Court powers to adjudicate on electoral issues or matters arising thereof." 86

The judges have also employed extrajudicial advocacy strategies in an attempt to bolster their legitimacy. In the Hadijatou Mani Koraou slavery case, ${ }^{87}$

83 See, e.g., Lydia Polgreen, Court Rules Niger Failed by Allowing Girl's Slavery, N.Y. TimES, Oct. 28, 2008, at A6, available at http://www.nytimes.com/2008/10/28/ world/africa/28niger.html; Nigeria: Ground-Breaking Judgment Calls for Punishing Oil Companies Over Pollution, Amnesty InT'L (Dec. 17, 2012), http://www.amnesty.org/en/news/nigeria-ground-breaking-judgment-callspunishing-oil-companies-over-pollution-2012-12-17; ECOWAS Court Orders Gambia to Pay Musa Saidykhan \$200,000 in Landmark Case, Jollofnews (Dec. 16, 2010), http://www.jollofnews.com/human-rights/1629-ecowas-courtorders-gambia-to-pay-musa-saidykhan-200000-in-landmark-case-; West Africa: ECOWAS Court Orders Nigeria to Provide Free Education for Every Child, VANGUARD (Nov. 30, 2010), http://www.vanguardngr.com/2010/11/ecowascourt-orders-nigeria-to-provide-free-education-for-every-child/.

84 SERAP v. Fed. Republic of Nigeria, ECW/CCJ/RUL/09/09 (Oct. 27, 2009), reprinted in Compendium of African Sub-Regional Human Rights Documents, supra note 70, at 298.

85 See, e.g., SERAP v. President of the Fed. Republic of Nigeria, ECW/CCJ/ RUL/09/10 (Dec. 10, 2010) (dismissing complaint against multinational oil companies alleging human rights violations in the Niger Delta); David v. Ambassador Ralph Uwechue, ECW/CCJ/RUL/04 /10 (June 11, 2010) (holding that the ECCJ has no jurisdiction to adjudicate human rights suits against individuals); Garba v. Republic of Benin, ECW/CCJ/JUD/01/10, ๆ 39 (Feb. 17, 2010) (dismissing a complaint that failed to satisfy the burden of proof and stating that applicants must provide evidence of alleged violations that is "sufficient, convincing, and unequivocal").

86 Jerry Ugokwe v. Fed. Republic of Nigeria, ECW/CCJ/APP/02/05, \ 19 (2005), reprinted in 2004-2009 CMTY. Cт. OF Just., ECOWAS LAW Report 37 (2011). We discuss this case in detail in Alter, Helfer \& McAllister, supra note 67.

87 Hadijatou Mani Koraou v. Republic of Niger, ECW/CCJ/JUD/06/08 (Oct. 27, 2008), reprinted in Compendium of African Sub-Regional Human Rights 
for example, the court changed the venue of the proceedings, temporarily relocating to the Nigerien capital Niamey to hear testimony and arguments from the parties and to deliver a judgment finding that the state had violated the applicant's human rights. ${ }^{88}$ The judges' physical presence in the capital was, according to lawyers involved in the litigation, an important factor in the government's decision to comply with the remedies awarded by the ECCJ. ${ }^{89}$

The judges also continue to publicize the court and its activities by giving speeches, issuing press statements, and traveling across West Africa to meet with bar associations, judges, and NGOs. ${ }^{90}$ In 2011, for example, the ECCJ celebrated its tenth anniversary with a burst of activity intended to raise the court's profile, including meetings with national supreme courts' judges. ${ }^{91}$ The ECCJ has also attempted to address the concern that some states are ignoring its judgments. For example, the ECCJ President has publicly "decried the attitude of the Nigerian government for not honoring any of [the court's] 10 rulings." The President suggested that Nigeria's noncompliance may not have been deliberate, and she praised a recent effort to identify a specific government official - the Attorney General - to oversee implementation of ECCJ judgments. ${ }^{92}$

DocumENTS, supra note 70 , at 286. The ruling also received widespread global media coverage. See, e.g., Christophe Châtelot, Une Cour Regionale Africaine Condamne le Niger pour Esclavage [A Regional African Court Condemns Slavery in Niger], Le Monde, Oct. 27, 2008, http://www.lemonde.fr/afrique/ article/2008/10/28/une-cour-regionale-africaine-condamne-le-niger-pouresclavage_1111928_3212.html; Mike Pflanz, Former Slave Wins Historic Case Against Niger Government, TelEGRAPH, Oct. 28, 2008, http:/www.telegraph. co.uk/news/worldnews/africaandindianocean/niger/3268371/Former-slavewins-historic-case-against-Niger-government.html; Lydia Polgreen, Court Rules Niger Failed by Allowing Girl's Slavery, N.Y. Times, Oct. 27, 2008, http://www. nytimes.com/2008/10/28/world/africa/28niger.html.

88 The ECCJ sits in the Nigerian capital of Abuja. However, the 1991 Protocol provides that, "where circumstances or the facts of the case so demand, the Court may sit in the territory of another Member State." Protocol A/P.1/7/91, supra note 70, art. 26(2).

89 Helen Duffy, Hadijatou Mani Koroua v Niger: Slavery Unveiled by the ECOWAS Court, 9 Hum. RTs. L. Rev. 151, 157 (2009).

90 E.g., Press Release, Media Foundation for West Africa, MFWA Holds Forum On ECOWAS Court in Abuja (July 27, 2012), available at http://www.mediafound. org/index.php?option=com_content\&task=view\&id=857.

91 Cmty. Ct. of Just., ECOWĀS, Summary of Activities for the Year 2011, at 5 (2012), available at http://www.courtecowas.org/site2012/pdf_files/annual_reports/ activities_report_2011.pdf.

92 Eyo Charles, West Africa: Nigeria Doesn't Respect Our Rulings - ECOWAS 
The ECCJ is still a young court, and its future remains uncertain. As we discuss elsewhere, ECOWAS officials and most governments have publicly expressed their support for the court and have taken concrete steps to bolster its independence. Most notably, in 2007 they created a Judicial Council to depoliticize the appointments process and encourage the election of highly qualified judges. At the same time, continued noncompliance by Nigeria, the regional hegemon, and an attempt (albeit ultimately unsuccessful) by the Gambia to narrow the court's jurisdiction suggest that the ECCJ's authority and legitimacy are not yet firmly established. ${ }^{93}$

\section{Conclusion: Lawmaking ANd Legitimacy Revisited}

This Article has documented a divergence in the penchant for judicial lawmaking by three international courts. The courts' distinct trajectories provide empirical evidence at odds with the conventional wisdom that expansive judicial lawmaking undermines IC legitimacy, and the implied corollary that conservative interpretations contribute to such legitimacy.

Most of the CJEU's expansionist jurisprudence, including its review of alleged human rights violations and its assertion of the direct effect and supremacy of European law, has been accepted by national decision-makers. Indeed, these ambitious - many would say audacious - legal doctrines are generally seen as enhancing the CJEU's legitimacy. In contrast, the ATJ engages in very little lawmaking, but its cautiousness does not appear to have bolstered its legitimacy. Officials in domestic IP administrative agencies and private IP attorneys see the ATJ as competent and authoritative, and its rulings in that issue area are influential and respected. But the court is barely known outside of this small and technical community, and the ATJ's narrow, formalist interpretations have left little imprint on other government policies. In West Africa, the ECCJ avoided CJEU-style expansionism in its first case and instead sought explicit member state support for broadening its jurisdiction to include human rights. The ECCJ has also required litigants to provide convincing evidence before finding violations of international human rights law. Yet notwithstanding this circumspect approach, the ECCJ's legitimacy remains uncertain.

Court, Daily Trust (Mar. 13, 2012), http://www.dailytrust.com.ng/index.php/ other-sections/law-pages/166086-nigeria-doesnt-respect-our-rulings-ecowascourt.

93 For further discussion, see Alter, Helfer \& McAllister, supra note 67. 
These findings reveal that, of the ICs we have discussed, those that have experienced legitimacy challenges have also issued politically consequential rulings that governments or other influential domestic actors disfavor. This leads us to suggest a conjecture for future research - that ICs spark controversy due to the domestic political consequences of their rulings, whether or not those rulings are expansionist.

This claim is consistent with explanations of how the CJEU engaged in expansionist lawmaking without provoking the wrath of member states. Karen Alter explained this puzzle by pointing out the different incentives and time horizons of politicians and judges. Many politicians care about providing short-term benefits to influential constituencies and being reelected to office. They have little incentive to oppose expansive IC lawmaking that does not interfere with these goals. Judges can take a longer-term perspective. They can build legal doctrines slowly, focusing on cases that create the foundation for future expansive lawmaking but that have limited short-term political impact. ${ }^{94}$

If correct, our conjecture has several important implications for IC legitimacy. First, political protests against IC rulings may be caused neither by judicial lawmaking nor by crises of legitimacy. A court that is controversial is not the same as one whose legitimacy is suspect. An IC that issues decisions reflecting the preferences of a majority of states, mobilized interest groups, or broader publics may be widely seen as legitimate. Nevertheless, those actors whose goals and objectives are threatened by an IC activities may still object to the court or its rulings. Since such challenges often invoke the mantra of judicial activism, we expect assertions of expansive lawmaking to be raised even when judges are applying well established doctrine or hewing closely to the court's jurisdictional mandate. But our intuition is that these claims will often be irrelevant or raised as smokescreens for other objections to the IC or its rulings.

Second, expansive lawmaking that is supported by key domestic actors such as national judges, bar associations, civil society groups, or administrative agencies - may bolster rather than undermine an IC's legitimacy. Such lawmaking may be especially welcome where a government's political branches fail to resolve pressing problems. By addressing such problems, ICs may attract support from these domestic actors even if their intervention requires significant judicial creativity.

Third, a court that issues narrow, technical or constrained judgments is not necessarily protected from controversies or backlashes. Judges may upset powerful political actors when they rule against them. But if judges are timid

94 On the different time horizons and incentives of judges versus politicians, see Alter, supra note 46, at 118 . 
when litigants present clear violations of the law, they may undermine their reputation for independence and compromise their legitimacy in the eyes of key interlocutors and compliance constituencies.

We are far from proving these conjectures. The next step is to examine the legal, political, and social contexts in which different ICs suffer crises of legitimacy or provoke backlashes. Our modest contribution in this Article is to explain why such research should not assume that legitimacy crises and political backlashes are linked. Rather, the connection between the two is an open issue to be explored. 
